\title{
European Policy for the Promotion of Inland Waterway Transport - A Case Study of the Danube River
}

\author{
Svetlana Dj. Mihic and Aleksandar Andrejevic \\ Faculty of Business and Law Studies, Novi Sad \\ Serbia
}

\section{Introduction}

Sustainable development, as a global development concept, represents a multi-dimensional phenomenon and it includes many different indicators of human activities. When trying to view such a large concept it is necessary to individualize, measure and follow the movement of those indicators that are considered the most important and the most influential from the point of view of sustainability of future development. In certain number of cases, big changes in values of some indicators do not have a significant influence. However, indicators that show the state of the field which is exploited and use of energy belong to the group of the most important indicators of sustainable development in general [1].

In all fields of human activity, certain forms and amounts of energy are used in different ways and with a different efficiency degree, which depends on a big number of diverse factors. Anyhow, theory and practice show to the fact that transport in general is absolutely the biggest energy consumer and contributes to pollution in biggest amount [2]. That being said, a lot more attention needs to be devoted to consideration and implementation of solutions that will lead us to the lower energy consumption and lower exploitation for transportation needs.

In traditional sense, we can talk about air, land and water transport. Water transport is considered ecologically most acceptable for several reasons. Above all, in order to carry out water transport, natural waterways (rivers, canals, seas and oceans) are used, with the use of some waterways whose purpose is to shorten the distance during a certain trip. Another point is that, while conducting a water transport, many modern high-capacity means of transport are used and they allow heavy load transport. Apart from all of this, these means of transport can use ecologically acceptable fuels, especially biodiesel and its blends. Water transport, if conducted properly, does not jeopardize environment too much, it does not create waste, it does not create much pollution and it does not harm the view of the landscape, which can entirely retain its characteristics. Lastly, it is important to say that the economists today completely agree on one thing - water transport is absolutely the cheapest way of transport nowadays.

Because of everything above-mentioned, in all European countries, as well as inside the European Union, the possibilities to exploit and to use these existing waterways are 
seriously considered. Namely, the analyses show that there is an extremely well-developed network of waterways in Europe which are only partially used.

It has been estimated that around 30,000 kilometers of rivers and canals are running through Europe. They are evenly distributed in all European countries. Besides, in Europe there are some canals which were build on purpose and which connect north and south, east and west, Europe, Asia and the rest of the world. European rivers provide homes to some of the biggest and most developed capitals and cities. These areas are also famous for being the most developed ones and the most inhabited ones. In spite of favorable natural conditions, in the EU countries, water transport covers only 5.6\% of total land transport in those countries. In the most developed European countries (which belong to Rhine region) water transport is constantly decreasing. From $12 \%$ in 1970 to $7 \%$ in the year 2000. At the same time, the total transport increased for $18 \%$ in the period of 30 years.

In order to promote the total transport, European Commission passed a so-called White Paper " European Transport Policy for 2010: Time to decide" by which Europe declares its willingness to intensify river transport as an economic, efficient, reliable and ecologically acceptable way of transport [3]. Likewise, the Declaration of European Ministers of Transport signed in Rotterdam in September 2001 called upon Member and Accession States to implement Pan - European RIS by the year 2005 [4] .

The European Parliament resolution following the White Paper sided the creation of high performance, geographically-comprehensive information systems of inland waterways to be extremely important in this connection and asked the Commission to submit a proposal for harmonized technical provisions towards the implementation of River Information Services (RIS). In the session of the Transport Council of 9th October 2003, The Netherlands, supported by other Member States, welcomed the Commission's initiative to put forward a proposal for a Directive on River Information Services. Meanwhile, this resulted in a RIS Directive, which creates a European-wide harmonized framework for River Traffic Information Services in order to ensure compatibility and interoperability between current and new RIS systems and to achieve effective interaction between different information services on inland waterways of international importance [5].

The harmonized river information services (RIS) on inland waterways in the Community Directive was published in the official journal of the European Union on 30th of September 2005 and came into force on 20th of October 2005.

\section{Regional, continental and global relevance of Danube River}

Danube is, together with River Volga, the longest European river. The length of the river from its spring in Germany, to its mouth in the Black Sea is 2,850 km. Danube connects 10 European countries. Taking into consideration the strategic concept of Europe as a region with long term sustainability strategy, European Commission has started considering the important potential, ecologic and economic relevance of unexploited waterway transport, by which the biggest attention is paid to the most important European river- Danube. River Danube is a waterway which makes an integral part of Trans European Transport Network (TEN-T). Via canal network, Danube connects Rotterdam harbor in the Netherlands with the Black Sea, that is, with Russia on the east. Because of all of this, Danube is thought o be the most important river in Europe, if not in the world. 
Via Danube-Rhine-Main Canal, the length of waterway has been extended to 3,500km, and in that way western and south-eastern Europe have been completely connected. Danube has a navigable length of 2,411 km out of which $1,156 \mathrm{~km}$ ( or $48 \%$ ) are border sections. The countries which belong to Danube waterway are: Germany, Austria, Slovakia, Hungary, Croatia, Serbia, Romania, Bulgaria, Moldavia and Russia (via Black Sea). Given the position of Europe as a continent and considering the Danube's flow direction, this river can be seen as the "gate of Europe", that is it can be its water connection to Russia, Asia, Africa and via Mediterranean Sea it can be connected to the rest of the world (Fig. 1).

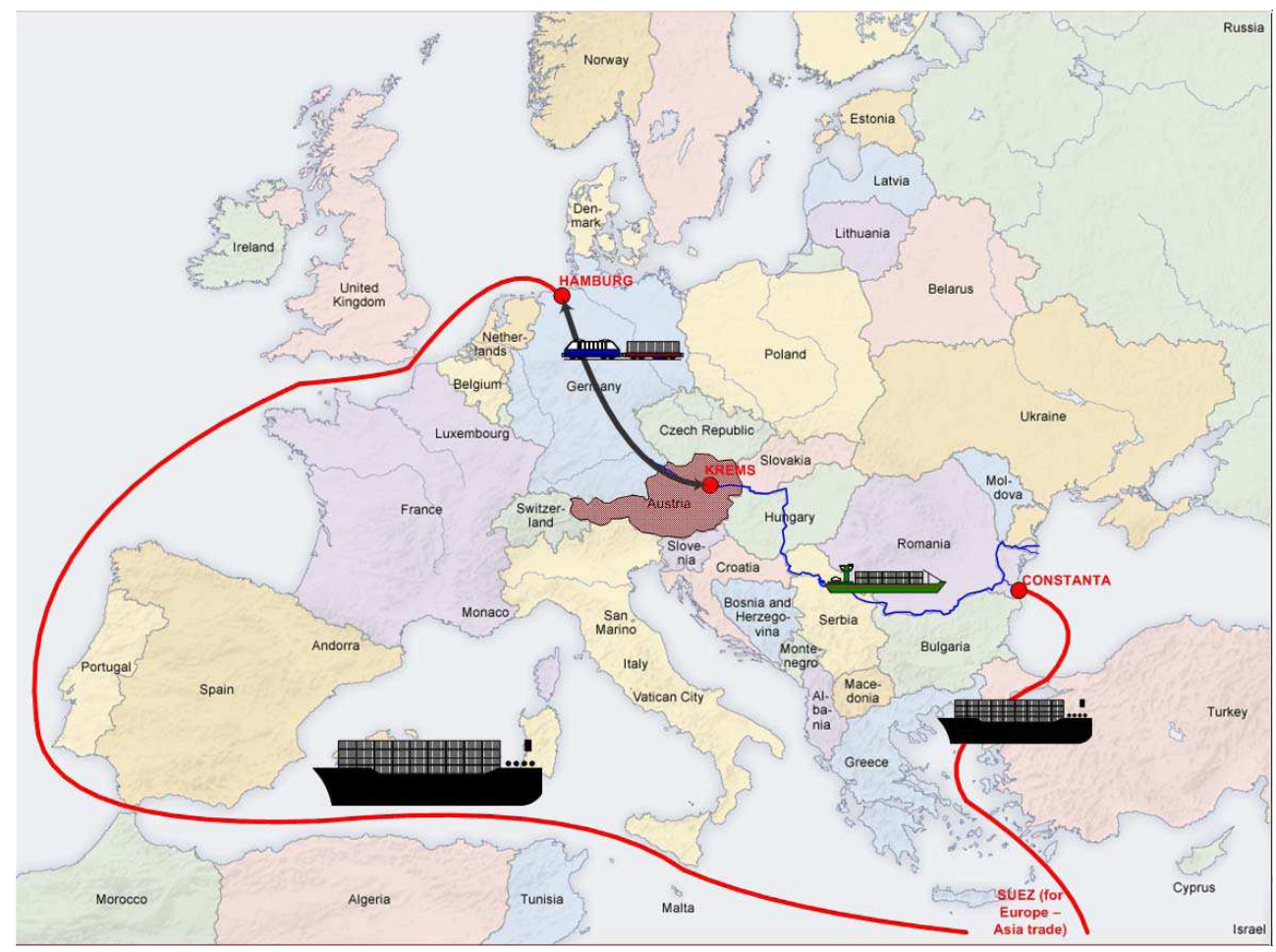

Fig. 1. Container Liner Services on Danube - Constanta as a gateway to Europe Source: Graphics: Austrian Institute for Regional Studies and Spatial Planning

Apart from its global relevance, Danube's water flow is of vital importance for entire Europe and especially for the region and the countries through which it flows. Danube has multiple significance for the development of the region. Above all, Danube represents the cheapest and ecologically the most acceptable way of transport. This fact is especially important if taken into account that Danube flows through and connects some of the highly developed world countries which constantly increase their level of export and import services, which, of course, requires quality and efficient transport.

Besides, Danube embodies a sort of ecosystem with its own characteristics and regions and cities which it flows through have great historical and cultural importance and hence act as a backbone for sustainable tourism in this part of the world. Danube region and its countries 
are in part the most developed European countries and in part there are countries which are on the road to economic development. The prognoses point to the fact that the other Eastern European countries will grow economically and more intensely in the following decade. Therefore, contemporary Europe thinks of Danube as of the basis for development of this region, it sees it as a connection between European Union, Balkan countries in south and Russia, which is considered a region with special development potential.

All countries that are on Danube flow have marked a significant degree in economic development. Ninety million inhabitants live in the Danube region and they produce a Gross Domestic Product (GDP) of around 450 billion euro. Based on the predictions made by BMVIT and European Commission, the average growth rate degree in some countries of this region could happen in the period between 2010 and 2015 and it could be considered extremely favorable. Namely, all Danube region countries will show growth of GDP. This growth is predicted to be of $2.2 \%$ per inhabitant in Germany and even $4.9 \%$ per inhabitant which is expected in Croatia. This positive trend will impose the need for more intense and for a better organized river transport on Danube [6].

The European Union believes that Danube should represent the point of integration in this region and hence help and accelerate the progress of less developed countries, especially in Croatia, Serbia and Turkey, which are the only countries out of the EU at the moment. The countries through which Danube does not flow could also profit from the upgrading of water transport, in an indirect way at least. All of the Danube region is expected to show an extremely encouraging period of economic growth, and as a consequence it will have higher needs for transport.

There is a wide range of speeds that Danube's flow can take. Near the spring of the river the average speed is $6.5 \mathrm{~km} / \mathrm{h}$. Near Vienna the speed is $6 \mathrm{~km} / \mathrm{h}$. Afterwards the speed slightly decreases so that when entering Romania it is $4.6 \mathrm{~km} / \mathrm{h}$ and on its way to the Black Sea the speed is $2.2 \mathrm{~km} / \mathrm{h}$. There are 78 bridges in total, whereas the biggest number of bridges is in bigger cities like Vienna and Budapest [7].

Regardless the fact that Danube does not flow through Russia, this country is extremely interested in Danube's waterway, especially given the fact that Russia borders with the Black Sea which represents the mouth of Danube river. Danube can be used for transport of natural resources and of products from Russia to the rest of the Europe and world, as well as vice versa. This fact shows how important is the need for a more precise long- term sustainable transport on this waterway.

\section{Transport research on Danube River}

Danube has been used for transport for a long time, but the precise data about transport on this river can be followed starting only from the year 1950, which was taken as the first year of the research. The final year of the research is 2005 or 2009 depending on the availability of the data. The data for the last year have been given in the form of an assumption, based on the movement on Danube in the last period, with a goal to get a clear and unique picture about character of transport on Danube in this period of 60 years, which was also the period of a strong economic development of Europe. The research covered the analysis of the following parameters [8]: 
- Description and analysis of the existing fleet;

- The amount and analysis of heavy load transport;

- The amount and analysis of passenger transport:

- The influence these characteristics had on ecology.

The analysis of the data was made based on the research results, and suggestions have been given on how to improve the quality and quantity of traffic on Danube, to make its sustainable use possible by giving a significant contribution to sustainable economic and ecological development of entire west, central and south-east region of Europe.

\subsection{Danube fleet}

The development of Danube fleet has been monitored statistically since 1962. For the needs of this research the authors had at their disposal the data for the period since 1965, taking into account that some data are registered every 5 years, so that the data for year 2010 were not yet available. The research shows that the number and the power of the fleet has been increasing year after year. The basic changes in the characteristics of the fleet used on Danube in the period from 1962 to 2005 are the following:

- The number of the entire fleet grew from 3,142 vessels in 1962 to 4,529 vessels in 2005 which represents growth of $144 \%$;

- The total heavy load which was transferred by the Danube fleet increased from $1,807,219$ tons in 1962 to 4,385,986 tons in 2005 which represents growth of $242 \%$;

- The biggest number of Danube fleet is used in Germany, Austria, Romania and Ukraine. The number of vessels in Serbia, Croatia and Moldavia is for 5\% lower than the total number of vessels on Danube.

These mentioned growths point to the fact that Danube fleet transports more and more heavy load but not due to the bigger amount of vessels but because their capacity and operational power grow. From the point of view of sustainable transport on Danube this tendency can be considered extremely favorable, being that energetic efficiency could be one of the key solutions to problems of energy consumption today.

\subsection{Heavy load transport}

The volume of heavy load transport on Danube has been monitored since 1965 and it includes the analysis of the amount of transported goods and the analysis of traffic in harbors on Danube River. The analysis in this field gave extremely precious data when talking about the possibility of realization of water transport on this waterway. Namely, the objective of this research is promotion and stimulation of efficient and ecologically acceptable transport of bigger heavy loads by waterway. The amount of load has been monitored on three different bases: the load which entered the river's flow from the Black Sea, the load which used Danube to get to the Black Sea as well as the load transported between Danube harbors without reaching the Black Sea. By analyzing these data the authors concluded that the transport on Danube in the last 40 years recorded 3 characteristic periods, as shown in Fig. 2.

First and foremost, this diagram shows that the total amount of heavy load transported on Danube increased 4.8 times in comparison to the initial year, that is 1950. During this period, 


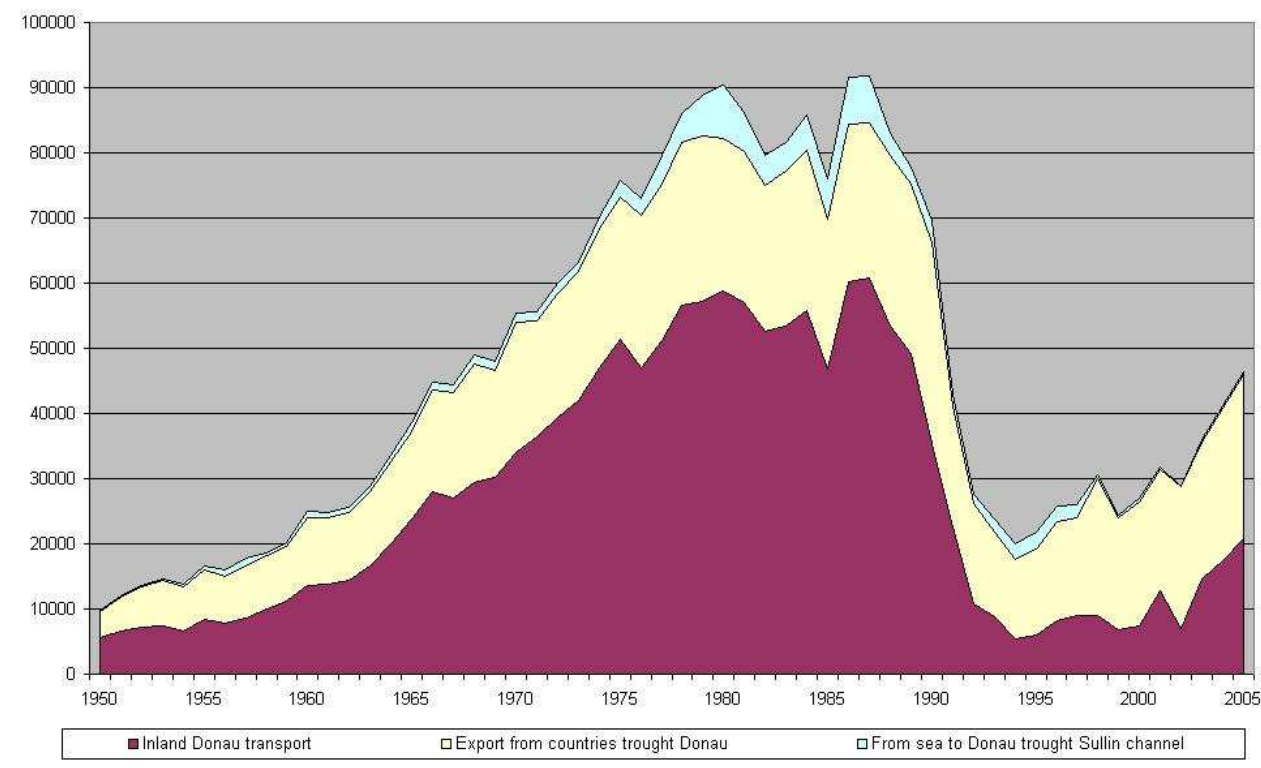

Fig. 2. The total of heavy load transported via Danube in the period from 1965 to 2005

the economic growth of some countries in this region directly affected the increase in transport as well. The growth registered each year reached its maximum in 1980 when a heavy load transport of 8 million tons was recorded. Such a high level of transported goods has been maintained until 1990. After that, there was a long period characterized by sudden decrease in the volume of transported goods, which is explained by the fact that transporters mostly used land transport. What brought to this decrease was also the worsening of economic and political situation and changes in countries of this region which belong to eastern Europe and in most cases they have accessed the process of political and economic transition. After the sudden decrease, the transport on Danube started recording some growth which was, however much slower so that in the last available year regarding the data(2005), the traffic equal to the traffic of 1970 was recorded. Because of these reasons, the promotion of Danube and sustainable transport development on it are of extreme importance.

The biggest volume of goods was recorded with the load entering the Danube through the Black sea. Somewhat less amount of goods refers to the goods transported between Danube harbors. The least amount of transported goods is represented by the goods which was imported from the countries of this region towards the Black Sea and further on. All this shows that in the past Danube, as well as now, has been used as a river by which different goods is imported in Danube region countries, and it is mostly referred to raw materials and unfinished products meant to be further processed. The least amount of goods is represented by raw materials or finished goods produced in the countries of this region and which are addressed to markets outside of Europe. It is very encouraging to see that transport among Danube harbors is well developed. The sustainable development of Danube traffic and this region as a whole insists on maximizing the use of Danube as means 
of road which can, whenever that is possible, substitute traditional land and railway traffic which represent much bigger a threat to the quality of the environment of this densely populated part of the world.

The biggest growth in the amount of transported goods was recorded in Romania, where transport increased 6.8 times respect to 1950. In the same period, the transport in Austria also increased, 5.7 times. The lowest growth was noted in Slovakia, 1.7 times.

Besides the general overview of transported goods in this monitored period, the traffic in harbors situated on Danube was also analyzed. The results of transport carried out in Danube harbors from 1965 to 2005 was given in Fig. 3.

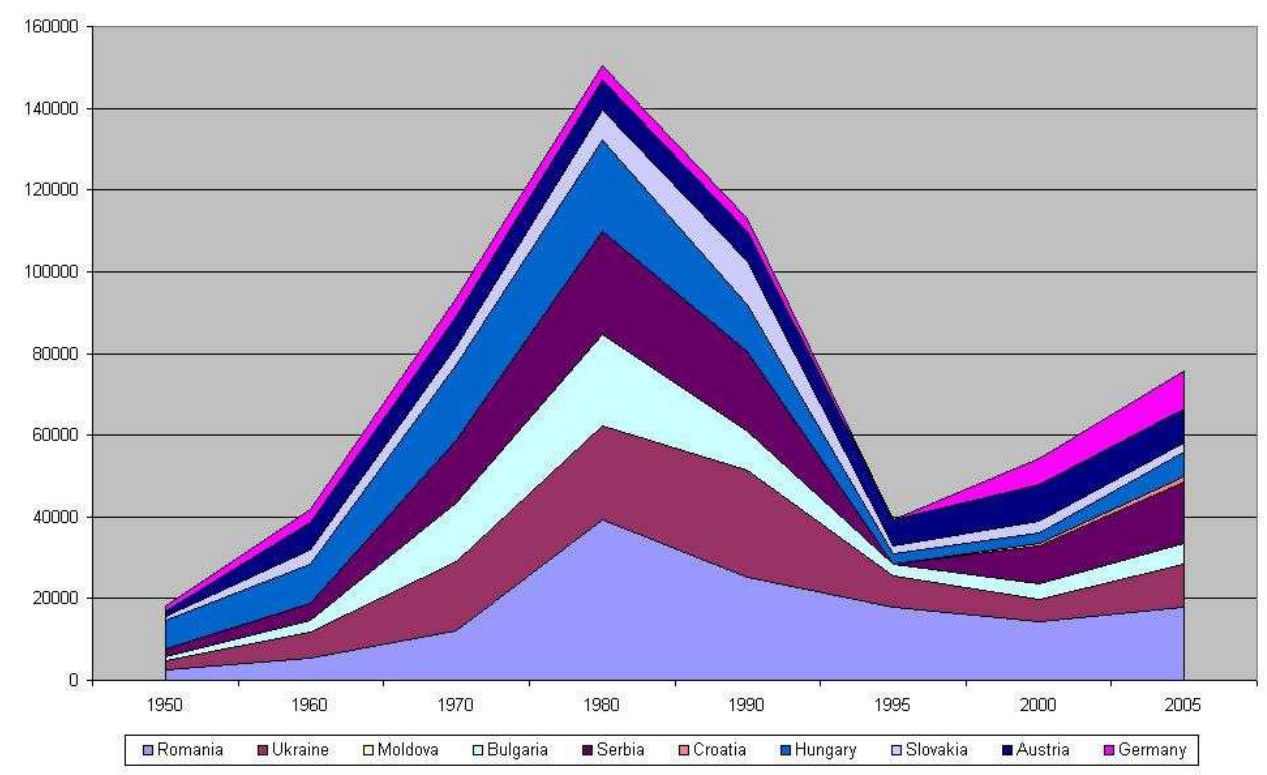

Fig. 3. The traffic in harbors on Danube divided by countries for the period from 1950-2005 (thousands of tons)

The traffic of goods in Danube harbors completely follows the tendency of transport on Danube in the monitored period. With the increase of transport of goods, the traffic in Danube harbors grew as well and it reached its maximum in 1980. After that the traffic in harbors suddenly decreases so that in 2000 it starts recording a new growth, with the expected positive tendency.

The biggest traffic was noted in harbors in Germany, Austria, Slovakia and Hungary, whereas the lowest values were recorded in Romania and Ukraine. Taking into account that Romania and Ukraine are as well the countries that have at their disposal $40 \%$ of entire Danube fleet, these results point to the fact that heavy load only travels through these countries but does not stop in their harbors. This situation opens the possibility for additional engagement of Ukrainian and Romanian harbors as a place for loading the goods produced in these countries. For the moment Danube in Romania and Ukraine has only a 
transition character. It is encouraging to know that traffic in Danube harbors in Serbia is increasing, even though it is a country with the least developed fleet in comparison to the other countries from this monitored sample.

The goods transported via Danube is very diverse. Mostly there are iron ore $(25.6 \%)$, then processed and unprocessed metals $(22.7 \%)$, coal $(9.1 \%)$, oil and oil derivatives $(8.5 \%)$, cement $(7.5 \%)$, grain goods $(6 \%)$, processed metals of metal industry $(5.4 \%)$, natural resources: wood $(4.3 \%)$, colored metals ores $(3 \%)$, finished metal products $(2.7 \%)$ and the least transported goods is agricultural goods like fodder $(1.6 \%)$. These data show that Danube is not enough used for transport of agricultural products for no reason at all, especially given the fact that Danube flows through almost exclusively agricultural regions and where the production of food represents the basis for export of food from the countries of Danube region, above all for Hungary, Serbia, Croatia, Bulgaria and Romania.

\subsection{Passenger transport}

Passenger transport on Danube has been statistically followed from 1964 and the updated data have been available for the year 2005. Based on the general insight and for the needs of planning of sustainable transport on Danube, the analysis has been made regarding the changes in the number of transported passengers from 1964 to 2005 which is shown in Fig. 4.

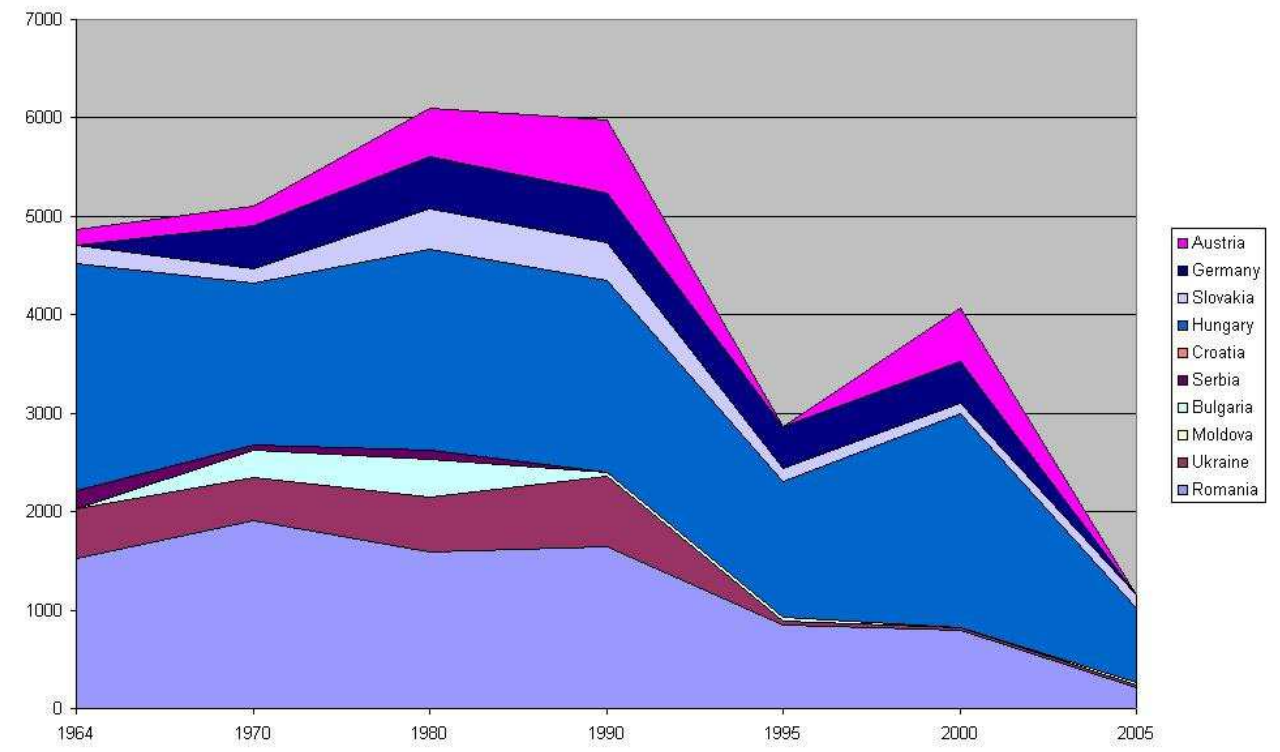

Fig. 4. Passenger transport on Danube from 1964 to 2005 (expressed in thousands)

Unlike the heavy load transport, where the constant growth was noted, passenger transport on Danube shows somewhat different characteristics. The biggest number of passengers was transported in the period between 1980 and 1990 (which coincides with the volume of 
the transported heavy load). Also, the biggest number of passengers was transported in Austria, Germany, Slovakia and Hungary. After that period, the passenger transport suddenly decreased and it reached its lowest point in 1995 which can be explained by the use of other, faster means of transport as well as by the wars and unstable political situation on the Balkans, given that general safety was very low and some of the bridges on Danube completely destroyed. After this period the number of passengers started growing rather insignificantly, for later it would start decreasing once again. The last year's data say that 1.2 million passengers were transported in 2005.

By monitoring countries, the biggest fall in number of passengers was noted in countries which at some point in past had the biggest number of passengers on Danube (Austria, Germany, Slovakia) which means that the promotion of water transport has to be adjusted to the requirements of the region. Also, based on this diagram it is easily noticeable that the number of passengers in Serbia is constantly low and it is especially surprising to know that there is a really small number of passengers in Romania, taking into consideration that Romania has big fleet. The fleet is primarily directed at heavy load transport, which means that planning the sustainable waterway transport must consider the investment projects to buy the fleet for transport of people.

\section{Ecology and transport on Danube}

Even though transport on Danube continues to show low intensity throughout the last 20 years the quality of the water has been harmed, being that there is a lot of waste water from many nearby industrial areas but also from cities located near the river. Regardless the strict laws which regulate the purification of water before letting it out, Danube has been significantly polluted. Given the impossibility to detect the sources of pollution, for the needs of the research the quality of the water has been decided not only based on the fact if it was pollution created by transport or in some other way.

Danube water in its upper waterway belongs to the II category ( there is a moderate pollution in the river and good oxygen supply, there is a diversity of species and an abundance of algae, insect larvae, snails, entomostracans, aquatic plants which can cover wide areas and there is a lot of fish diversity). This type of water quality can be considered satisfactory, being that Danube in its upper waterway flows through Germany and Austria which are the countries that have reached very high level of development. Certainly, adequate laws in these countries (as well as in the EU in general) contribute a lot to these relatively good parameters of quality of Danube water in this area.

After going through Vienna, the capital of Austria, Danube water loses on quality and it changes to the III category (higher organic pollution; rather low oxygen content which affects fish; local sludge deposition; frequent and mass occurrence of sewage bacteria and ciliates; sponges, leeches and isopods can be often found; scarce aquatic vegetation ). At some points going downstream from Vienna, the quality decreases even more and it become the IV category water (restricted living conditions for higher life forms; extremely high organic pollution; highly infected by organic, oxygen-depleting wastewater; total oxygen depletion is often caused by bacteria, flagellates and ciliates; suspended wastewater constituents cause turbidity or haziness; dense population of larvae and oligochaeta.) 
Going through Hungary and reaching Belgrade, the capital of Serbia, the Danube water situation changes once again. It becomes the $\mathrm{V}$ category water and going downstream all the way to the Black Sea, Danube water is extremely polluted and at certain points it is even considered to be of VI or VII category [9]. Such a low water quality in this area is not so low only due to the highly developed industry, given that these are countries with a lower development level, but the insufficient and inadequate laws regarding environment.

The traffic on Danube affects the quality of Danube water depending on the quality of the fleet and on the frequency of ecological incidents. Given the age of the Danube fleet, European Union started a whole range of initiatives whose goal is to upgrade the quality of Danube water in its entire flow. For that reason, The Danube River Protection Convention has been enforced. It was created in the framework of the ECE - Convention for protection of trans-boundary waters that was enforced in 1998 and it is the only legal document regulating the transport on Danube and it includes Danube's tributaries as well. The basic objectives of this Convention are:

- Sustainable development and use of Danube as water resource and natural wealth of common interest

- Control of pollution of Danube

- Preventing further pollution of Danube

- Ecologically and economically justified use of Danube

- International collaboration

- Promotion of water transport

- The use of ecological energy as power generating fuel

The importance of Danube waterway for the EU can be seen in the fact that at the moment there are over 400 different projects on Danube which are being prepared or are already in process and their total value is around 5 billion dollars [10] and this money is to be distributed in the following way:

- Municipal waste water collection and treatment plants: 3.57 billion US dollars

- Industrial waste water treatment: 0.81 billion US\$

- Agricultural projects and use of land: 0.16 billion US\$

- Rehabilitation of wetlands: 1.12 billion US\$

Bearing in mind that Danube waterway is very important and taking into account how much money has been invested into these projects, their realization is conducted under the supervision of the EU and it is conducted in 3 phases. In the first phase, completed in the end of 2003, the definition of Danube basin and Danube region was conducted together with conducting the analysis and upgrading the institutional frame necessary for collaboration among Danube areas and countries. The second phase of this enormous project was finished until the end of 2006, and it covered the analysis of the quality of Danube water, definition of ecology and source of pollution, as well as ways to control and monitor. After this phase there was a possibility to define clear strategic objectives and ways to realize them. In majority of Danube countries the third phase of the project is taking place. It covers conduction of certain activities. Given the character and volume of planned measures, the end of the first phase will be finished in 2021, even though there are some indications that it could last until 2027. All these things point to the need of clear and precise planning in all fields regarding the use of Danube, especially regarding the planning of sustainable traffic. 
Its intensification has been predicted, and this fact in uncontrolled conditions can lead towards highly increased ecologic pollution.

\section{Improvement in use of Danube River waterway}

\subsection{European policy for the promotion of inland waterway transport}

In accordance with regulations conducted so far regarding the development of Europe, which is supported by the results obtained after the analysis of 60 years of Danube waterway, it is clear why all European countries support the development to intensify transport on Danube, certainly by respecting the concept of sustainability of transport and development in general. Considering the fact that Danube's potential has not been used enough, the new concept was defined as an all-embracing basis for the promotion of inland waterway transport. The name of the project is PLATINA.

Realization of Danube waterway promotion is connected to a lot of different problems which, above all, refer to the different levels of economic and institutional development of the countries through which Danube flows. The need for sustainable use of one river is possible only if all the activities, whose primary objective is equalization in position of some countries, are performed. Only in this way will it be possible to see Danube as unique, undivided and safe waterway, from source to mouth of river. For that reason, PLATINA projects points out the following primary activities :

- Establish a knowledge network bringing together all relevant actors concerned to assist in the implementation of NAIADES in Europe (EC, Member States and third countries),

- Provision of technical expertise and support,

- Provision of organizational, infrastructural and financial support and

- Platform deals with areas that require non-legislative coordinative actions at the European level.

These activities will be adjusted to the needs of each country. In order to proceed with efficient implementation of Danube promotion project, it is first necessary that every country makes its own personal action plan, which has to cover the following parts:

- Improvement and maintenance of waterway infrastructure

Each country that uses Danube waterway shows different quality of river and transport infrastructure. That being said, it is necessary that all the countries be put in the state which will suit the requirements of contemporary river transport [11].

- Exploitation of Danube's waterway potential

The results of this and similar researches confirm the fact that Danube's waterway is not being sufficiently used. Besides, the economic predictions of intensity regarding the economic development of Danube region in the following decades shows that there will be higher growth in industrial development and that imposes the need for more intense transport. Because of this, every country needs to think of Danube's waterway as of one of the most dominant existing waterways in the future [12].

- Building capacity for waterway and navigation authorities as well as for related administrations 
The development of administrative and institutional systems which provide support and which intensify transport on Danube.

- Implementation of River Information Services on Danube

To create and implement the unique RIS system in all the Danube region countries represents one of the most important conditions for integration of the region [13]. In this way, Danube's waterway will surpass international borders and it will represent the unique waterway whose users will be able to use independent information and logistic support, which is something that will contribute to upgrading of the quality of sustainable transport.

- Implementation of Transport Management

The implementation of contemporary transport management primarily refers to providing the project with monitoring, control and navigation systems by which it is possible to control the traffic, to prevent delays, to reduce the cost of fuel and to reduce the cost of fleet maintenance $[14,15]$. Besides fleet control, contemporary or modern transport management provides some solutions to the synchronization of harbors, load and unload equipment, container services and it provides the solution for bridges on Danube's waterway.

- Modernization of the fleet

The results of the research show that there are unfavorable characteristics when it comes to vessels used for transport on Danube. Especially worrying indicators of quality of the fleet are noted in the lowest developed countries (Serbia, Moldavia). It is necessary to proceed with adequate adjustments of existing vessels and with the purchase of new vessels which according to their characteristics fit with modern day economic, transport and ecological requirements. At this point it needs to be said that all the countries in the region have good conditions for production of biodiesel [16], which is considered excellent when used in naval engines.

- Development and integration of ecological strategies and concepts for Danube River

Danube represents a unique ecosystem with lower characteristics in some of its parts. Besides, some parts of Danube river bank represent protected natural, cultural and historical places. Sustainable development of transport on Danube needs to provide preservation and improvement of ecological maintenance of these regions.

- Creation of an international traffic model for the Danube region

It is necessary to analyze the existing infrastructure that is directly or indirectly related to Danube's waterway. All forms of land transport that are connected to Danube (roads, railways) have to be considered a priority in terms of investments for maintenance and for extending capacities. Also, it is necessary to decide future transport corridors which will connect industrial and agricultural capacities to Danube. Special attention needs to be given to modernization of international transport corridors, borders and customs free zones.

\subsection{Applications and projects at work across Europe}

The realization of PLATINA project proceeds via wide range of special projects whose goal is to promote certain aspects of inland waterway transport. All the mentioned projects are 
ongoing and each of them affects the creation of sustainable transport on Danube, as well as on other waterways in Europe. Due to the canal connection of rivers Danube, Rhine and Main, these projects cover almost entire territory of central, northern and southern Europe. The developments of national stand-alone telematics services, which vary in functions, standards and architecture, brought challenges to the current service regime. Some of the existing applications are $[17,18]$ :

- ARGO (Advanced River Navigation), a German navigation system for inland waterway skippers. It provides data on the fairway conditions and actual water levels in real time.

- BICS (Barge Information and Communication System) is a voyage and cargo (especially dangerous cargo) reporting system used in The Netherlands, Germany and other countries. The main aim of BICS is to support the reporting duties of the skipper/fleet operator towards the authorities.

- $\quad$ BIVAS (Inland Navigation Intelligent Demand and Supply System) is an internet-based interactive freight transport virtual marketplace.

- DoRIS (Donau River Information Services) is an Austrian system that can automatically generate traffic information by means of AIS transponders. The tactical traffic image is currently being tested for use by waterway authorities and skippers. In 2005 the roll-out of the DoRIS systems was performed on the Austrian section of the Danube and the operational test started in the beginning of 2006. Furthermore a subsidy program for RIS equipment is being provided for accelerating the penetration of RIS on the userside.

- $\quad$ ELWIS, a German Electronic Waterway Information System, which provides a series of (fairway) information services.

- IBIS (Informatisering Binnenscheepvaart), a Flanders centralized database system, allows administrations to deliver navigation licenses, locate ships within their territory and collect data on inland navigation.

- GINA (Gestion Informatisée de la Navigation), a reporting application for Wallonia dedicated to the invoicing of navigation fees and the generation of statistics.

- IVS90, a ship reporting system used by Dutch waterway authorities supporting lock planning, vessel traffic services, calamity abatement and statistics.

- NIF (Nautischer Informations-Funk), a German service to transmit messages related to water levels, high-water notifications, water level predictions, ice and mist messages, and police messages.

- VNF2000, a French information network used to invoice navigation tolls and to produce traffic statistics.

- VTS's Rhine, Vessel traffic management services are installed on the Rhine in two difficult stretches: in the gorge section reach around the Lorelei in Germany with narrow bends and strong currents, and on the meandering Lower Rhine in The Netherlands with heavy traffic These differing operational practices and facilities in Member States reflect the current incompatibility of information systems, standards, and installations. Legislative and technical support for harmonized information services at a pan-European level become more and more necessary to guarantee the efficiency and safety for cross-border navigation and logistics. This was one of the principal motivating factors in the development. 
Planned infrastructure projects:

- Germany: Straubing - Vilshofen (Danube km 2,321 - km 2,249)

- Austria: Vienna - cross border section with Slovakia (Danube km 1,921 - km 1,873)

- Hungary: Palkovicovo - Mohacs (Danube km 1,810 - km 1,433)

- $\quad$ Bulgaria - Romania: Iron Gate II - Calarasi (Danube km 863 - km 375)

- $\quad$ Romania: Calarasi - Braila (Danube km 375 - km 1,75)

The number and volume of mentioned investment projects show that modernization of Danube water way represents one of the most important initiatives which lead towards economic and ecological improvement of the region, which is based on sustainability and long-term stability.

\subsection{Development and implementation of RIS}

River Information Services (RIS) are the harmonized information services that support traffic and transport management in inland navigation, including interfaces to other transport modes. RIS do not deal principally with internal commercial activities between companies, but is available for interfacing with commercial processes. RIS streamline information exchange between public and private parties participating in inland waterborne transport. The information is shared on the basis of information and communication standards [19]. The information is used in different applications and systems for enhanced traffic or transport processes.

Modern logistics management requires extensive information exchange between partners in supply chains. Implementation of communications and information technologies in organizational and operational processes is a crucial prerequisite to increase operational efficiency and safety in today's market. RIS facilitate the inland waterway transport organization and management. Through effective information exchange, transport operations (such as trip schedules and terminal/lock operation plans) could easily be optimized, providing advantages for inland navigation and enabling it to be integrated into the intermodal logistic chains [20].

The degree of RIS system development in some Danube countries is different [21] but it is also conditioned by the influence of a big number of complex factors. The influence of the RIS development degree on the development of sustainable water transport is extremely intense, hence a short overview of its development in some countries is shown in further text.

Germany is one of the most developed world countries and it has a fully developed and implemented RIS system. The situation is similar in Austria as well. In this country there is a separate RIS centre which coordinates the functionality of the system in the entire territory of the country. The system of water level information, skipping service as well as availability of tactical traffic information all function. Electronic reporting system is still in development. The situation is similar in neighboring countries, Slovakia and Hungary [22, 23].

Somewhat more unfavorable situation regarding this issue is noted in Moldavia. Instead of fully developed RIS system, in Moldavia there is a tactical information transport center. There is no skipping service. In Romania all VTS centers are functional throughout the 
entire Danube waterway and there is also the skipping service. The full implementation of RIS system is in process and it is conducted with the help of the adequate EU institutions. In Bulgaria the situation is almost the same with the difference that in Bulgaria there is no skipping service.

Regardless of the fact that Croatia does not belong to EU, this country has a quality and well implemented RIS system. Water level and tactical information services are provided and there is also a skipping service. Electronic reporting system is in the process of development. The most unfavorable situation is in Serbia. In this country there is only one center that can provide with traffic information whereas the full implementation of RIS system still in process and it is supervised and helped by the EU.

\subsection{The promotion of Danube waterway}

The whole EU strategy is based on promotion and realization of conditions necessary for development of countries in this part of the world as well as all the activities conducted in them. Because of this, the special attention needs to be given to changes in traffic field which at the moment represents the biggest pollution threat for the environment. Based on the dimension of the problem and complexity of traffic in Europe, an all-inclusive sustainable development strategy, which concerns, apart from the other things, intensifying of water traffic in European waterways. These objectives are directed towards sustainable development of traffic and they include complex activities which have been going on for more than 20 years and therefore require special intensive and efficient promotion [24].

In Europe there are many organizations which deal with promotion of Danube waterway and they have the same objective to make Danube an intensive and ecologically more acceptable waterway in the future. If this balance of sustainability is reached, the stability in quality of Danube and river bank area, as well as improvement of quality of life of this area's inhabitants is provided. Given the importance of this problem and considering the number and diversity of Danube region countries, many governmental and non governmental organizations follow and support the promotion of Danube waterway. Some of the most important are:

- Danube Commission with headquarters in Budapest, capital of Hungary, is at the moment the most important international organization which deals with regulation, promotion and implementation of sustainable transport on Danube. This organization consists of all the countries that can be found on Danube's waterway, including Russia, which is connected to Danube via Black Sea. The main source of finances of this commission is the fund of all country members.

- UN Economic Commission for Europe, Inland Transport Committee, the organization with headquarters in Geneva, Switzerland. The main goal of this organization is the technical development on inland transport as well as the development of laws and regulations in this area. This organization is financed by the UN.

- European Conference of Ministers of Transport gathers all the transport ministers of all European countries whose objective is the implementation of all sustainable and ecologically acceptable forms of transport on the territory of entire Europe. The sustainable development of traffic on Danube is one of the priorities of this organization whose headquarters are in Paris and is financed by European countries. 
- Transport Infrastructure Needs Assessment: Corridor 7 is the association dealing with the development of transport infrastructure in inland waterways and it is financed by the EU Commission for the development of traffic. The headquarters of this organization are in Vienna, capital of Austria.

- Southeast European Cooperative Initiative: Danube Transport Working Group is the organization of Danube region countries with headquarters in Vienna. This organization deals with the development of traffic on Danube and it is financed by the EU member countries and by the USA.

- Stability pact for South Eastern Europe is a special organization in the EU, founded with the objective to support and provide stable development of countries in this region which were over the past years exposed to a number of negative influences. The headquarters of this organization are in Brussels, Belgium.

- Joint Austrian/Romanian initiative; Danube Co-operation Process is an association which stimulates the cooperation among all the countries which are situated on Danube waterway and its goal is to decrease border issues and limitations. It is financed by Riparian states, Stability Pact and European Commission.

- Via Donau is founded and financed by Austria, with headquarters in Vienna. The main goal of this association is improvement in quality and long-term sustainability of river traffic and implementation of RIS system on entire Danube waterway.

This is an overview of the most important organizations which deal with promotion of Danube waterway from different aspects. Their number, importance and financial sources speak about the relevance that sustainable development of Danube waterway has in all the countries of Danube region and in Europe in general.

\section{Conclusion}

The development of inland waterway transport is one of the long-term priorities of sustainable development of EU. Danube and Rhine- Main Canal as well as Danube's tributaries represent the most important waterway in Europe, therefore the biggest efforts of EU are put in analysis and improvement of sustainable water transport on Danube waterway.

By analyzing the available data which refer to the use of Danube waterway in period starting from 1950, it was stated that Danube waterway was used for the needs of traffic with different intensity. By analyzing the amount of freight transport, the number of passengers and heavy load in Danube harbors it is confirmed that Danube was intensely used as a waterway up until 1990 and after that its popularity decreased. After the year 2000, with the beginning of all-inclusive initiative of EU on promotion of inland water transport, some growth in use of Danube was noticed but that growth cannot be considered sufficient neither acceptable.

Therefore in Danube region countries, as well as in EU as a whole, many projects have been developed and there are many ongoing activities which were explained in this research. The objective of all these things is to promote and improve sustainable water transport on Danube. These activities mostly refer to modernization of Danube fleet (with emphasis on use of biodiesel as a power generating fuel), construction of adequate infrastructure, development and implementation of a unique information system on Danube as well as 
many promotional activities. EU predicts that the first phase of the activities, which deals with improvement of sustainable water transport on Danube, will be over in 2027.

\section{References}

[1] Mirjana Golusin, Olja Munitlak Ivanovic, Definition, characteristics and state of indicators of sustainable development in countries of Southeastern Europe, Agriculture, Ecosystems and Environment, vo. 130, issues 1-2,(2009), 67-74.

[2] Olja Munitlak Ivanovic, Mirjana Golusin, Sinisa Dodic, Jelena Dodic, Perspectives of sustainable development in countries of Southeastern Europe, Renewable and sustainable energy review, Vol. 13, Issue 8, (2009),pg 2179-2200.

[3] White Paper "European Policy for 2020: Time to decide", European Commission "Declaration of Rotterdam", Pan European Conference on Inland Waterway Transportation, September (2001) 58-62.

[4] DoRIS “Donau River Information Services", http:/ / www.doris.bmvit.gv.at/

[5] The strategic importance of the Danube for a sustainable development of the region, Workshop "Cross-programme ETC Danube projects", Austria, 2009.

[6] Danube waterway - European key axis, OSCE, Economic and Environmental forum, Austria, 2008.

[7] Statistic ouverage 1950-2005, Donau Commision

[8] Jürg Bloesch, The International Association for Danube Research (IAD) - portrait of a transboundary scientific NGO, Environmental Science and Pollution Research, Springer, (2009), 23-29.

[9] ICPDR / International Commission for the Protection of the Danube River

[10] PINE "Prospects of Inland Navigation within the enlarged Europe", Feb 2003-Feb 2004, DG TREN project

[11] Reinhard Pfliegl via Donau - Danube Transport Development Agency Donau-CityStrasse 1, A-1220 Vienna, Austria

[12] “Guidelines and Recommendations of River Information Services", PIANC, 2002.

[13] THEMIS "Thematic Network in the Optimal Management of Intermodal Transportation Service", April 2000-April (2004), 5th Framework Programme thematic network, http:/ / hermes.civil.auth.gr/themis/project.htm

[14] COST 326 "Electronic Chart for Navigation" - European cooperation in the fields of scientific and technical research, 1994-1997, http:/ / www.cordis.lu/cost-transport/

[15] Doc Dr Svetlana Mihić Mr Saša Raletić, Kaizen kao način upravljanja performansama, XIV Medjunarodni naucni skup SM 2009 - Ekonomski fakultet Subotica, 21.0522.05 Maj (2009) Palić - Subotica Zbornik spg.55 ISBN 867233224-5 COBISS.SR-ID 239684103

[16] PINE "Prospects of inland Navigation in Enlarged Europe, SWP1.3 'Information and Communication systems' ", Feb 2003-Feb (2004), DG TREN study

[17] EMBARC "European Maritime study for Baseline and Advanced Regional and Coastal traffic management", Dec 2001-Nov 2004, 5th Framework Programme research project, http://www.euro-embarc.com/

[18] INDRIS "Inland Navigation Demonstrator for River Information Services", Jan 1998June 2000, 4th Framework Programme research project

[19] ALSO DANUBE “Advanced Logistic Solutions for the Danube Waterway"May 2000- May 2003, 5th Framework Programme research project http://www.alsodanube.at 
[20] COMPRIS "Consortium Operational Management Platform for River Information Services", Sept. 2002 - August 2005, 5th Framework Programme research project http:/ / www.euro-compris.org

[21] BICS "Barge Information and Communication System", http:/ / www.bics.nl

[22] D4D "Data warehouse for the Danube waterway",May 2001-May 2005, Interreg III B project, http://www.d4d.info

[23] SPIN-TN, "Strategies to Promote Inland Navigation”, June 2000-June 2005, 5th Framework Programme thematic network, http:/ / www.spin-network.org

[24] Doc. Dr Svetlana Mihić, Asis. Saša Raletić, Use of open inovation as possible marketing strategy in logistic, International Conference on Industrial Logistics " Logistic and Sustainability" March 8-th to 11-th, (2010) ICIL 2010 Rio de Janeiro Brazil ISSN: 2177-0514 Proceedings page no.191 


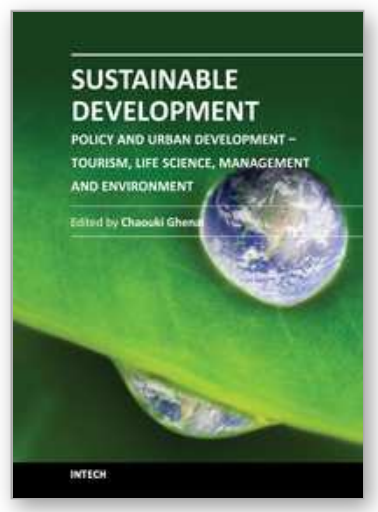

\author{
Sustainable Development - Policy and Urban Development - \\ Tourism, Life Science, Management and Environment \\ Edited by Prof. Chaouki Ghenai
}

ISBN 978-953-51-0100-0

Hard cover, 478 pages

Publisher InTech

Published online 24, February, 2012

Published in print edition February, 2012

The technological advancement of our civilization has created a consumer society expanding faster than the planet's resources allow, with our resource and energy needs rising exponentially in the past century. Securing the future of the human race will require an improved understanding of the environment as well as of technological solutions, mindsets and behaviors in line with modes of development that the ecosphere of our planet can support. Sustainable development offers an approach that would be practical to fuse with the managerial strategies and assessment tools for policy and decision makers at the regional planning level.

\title{
How to reference
}

In order to correctly reference this scholarly work, feel free to copy and paste the following:

Svetlana Dj. Mihic and Aleksandar Andrejevic (2012). European Policy for the Promotion of Inland Waterway Transport - A Case Study of the Danube River, Sustainable Development - Policy and Urban Development Tourism, Life Science, Management and Environment, Prof. Chaouki Ghenai (Ed.), ISBN: 978-953-51-0100-0, InTech, Available from: http://www.intechopen.com/books/sustainable-development-policy-and-urbandevelopment-tourism-life-science-management-and-environment/european-policy-for-the-promotion-of-inlandwaterway-transport-a-case-study-of-the-danube-river

\section{INTECH}

open science | open minds

\section{InTech Europe}

University Campus STeP Ri

Slavka Krautzeka 83/A

51000 Rijeka, Croatia

Phone: +385 (51) 770447

Fax: +385 (51) 686166

www.intechopen.com

\section{InTech China}

Unit 405, Office Block, Hotel Equatorial Shanghai

No.65, Yan An Road (West), Shanghai, 200040, China

中国上海市延安西路65号上海国际贵都大饭店办公楼405单元

Phone: +86-21-62489820

Fax: +86-21-62489821 
(C) 2012 The Author(s). Licensee IntechOpen. This is an open access article distributed under the terms of the Creative Commons Attribution 3.0 License, which permits unrestricted use, distribution, and reproduction in any medium, provided the original work is properly cited. 